\title{
South Africa Perspectives for BRICS - 'Finger Print' Profiling of the Trace and Heavy Metals in Ginseng and Hypoxis Commercial Available Herbal Products - A Quality Control Tool
}

\author{
Gary Gabriels ${ }^{1,3 *}$, Pete Smith ${ }^{2}$ and Yoga Coopoo ${ }^{1}$ \\ ${ }^{1}$ Department of Sport and Movement Studies, University of Johannesburg, South Africa \\ ${ }^{2}$ Department of Medicine, University of Cape Town, South Africa \\ ${ }^{3}$ Department of Pharmacy and Pharmacology, University of the Witwatersrand, Johannesburg, South Africa
}

Submission: December 01, 2017; Published: December 19, 2017

*Corresponding author: Gary Gabriels, Department of Pharmacy and Pharmacology, Faculty of Health Sciences, University of the Witwatersrand, Johannesburg, South Africa, Email : gary.gabriels@gmail.com

\begin{abstract}
Natural products extensive use as a source of primary health care requires routine quality control scientific testing methodologies, to verify the safety, quality and efficacy of commercially available plant products in the best interest of the consumer. This in context of the BRICS nation states will enhance public confidence in the use of such products, as adverse side effects, often associated with the use of traditional/herbal products are generally due to misidentification of plants, lack of standardization and good manufacturing practices, botanical substitution, adulteration, and contamination. The therapeutic effect of plant medicine is alleged to be enhanced by essential trace elements. For this study the focus was two product types; Ginseng as a popular traditional Chinese medicine, used for its adaptogenic and restorative properties, and African Potato products used as an immune booster for patients infected with HIV/AIDS. Different commercial brands of Ginseng and African Potato products were purchased from pharmacies and health stores in Cape Town. Products were evaluated for content validity and contamination for the following trace element and heavy metals, sodium ( $\mathrm{Na}$ ), potassium (K), magnesium (Mg), calcium (Ca), iron (Fe), zinc ( $\mathrm{Zn})$, manganese (Mn), copper $(\mathrm{Cu})$, chromium $(\mathrm{Cr})$, nickel $(\mathrm{Ni})$, lead $(\mathrm{Pb})$ and mercury $(\mathrm{Hg})$, lithium $(\mathrm{Li})$. The instrument utilized was the combination tandem system of Inductively Coupled Plasma - Mass Spectrometer (ICP-MS) that is a powerful, accurate, fast and sensitive, analytical technique. The results for Ginseng products show intra-sample and batch-to-batch consistency for $\mathrm{Mg}, \mathrm{K}, \mathrm{Ca}, \mathrm{Mn}, \mathrm{Fe}, \mathrm{Sr}, \mathrm{Cd}, \mathrm{Pb}$, and for Hypoxis products this was $\mathrm{Mg}$, $\mathrm{K}, \mathrm{Ca}, \mathrm{Mn}, \mathrm{Co}, \mathrm{Cu}, \mathrm{Zn}, \mathrm{Sr}, \mathrm{Cd}, \mathrm{Pb}$. These trace element and heavy metals could be used as 'markers' for product consistency. In conclusion, for the safety, quality and efficacy of these natural products standard operating procedures (SOP) for Good Agricultural Practice (GAP), Good Laboratory Practice (GAP), Good Supply Practice (GSP) and Good Manufacturing Practices (GMP) needs to be established, improved on, implemented and monitored. This approach with technology will help policy-makers and development agencies, within the BRICS nations, to ensure quality products and appropriate enforcement.
\end{abstract}

Keywords: Natural products; Ginseng; Hypoxis (African Potato); BRICS; Commercially available products; Trace elements and Heavy metals; GMP; Policy-makers and development

Abbreviations: CTMF: Complimentary and Traditional Medicines in Foods; SOPs: Standard Operating Procedures; GAP: Good Agricultural Practice; GLP: Good Laboratory Practice; GSP: Good Supply Practice; GMP: Good Manufacturing Practices

\section{Preamble}

This research paper seeks to illuminate an important requirement for laboratory (or improved) systems to monitor the quality and consistency of commercially available products as may be traded among emerging national economies of, Brazil, Russia, India, China and South Africa (BRICS). These plant-based products may previously have been used in traditional setting only, but demand by consumers in both rural and urban setting (migration to city) makes commercialization of such products or product equivalents attractive as enterprising business [1]. This is specifically so in context of the Human immunodeficiency virus/Acquired immunodeficiency syndrome (HIV/AIDS) setting, where the use of Ginseng and African potato is common practices. 


\section{Introduction}

The World Health Organization (WHO) estimates that 60$80 \%$ of people in developing countries use herbal (traditional) medicines [2]. Moreover, the use of over-the-counter (OTC) herbal and other forms of drugs derived from plants products (traditional medicine) has increased dramatically over the past decade, both in developing and developed countries [3].

\section{The upsurge in the use of natural products includes}

(i) Cost effectiveness and availability,

(ii) perceived safety and lack of side effects,

(iii) Deteriorated belief in the efficacy and safety of orthodox drugs,

(iv) Public tendency towards self - medication

Increase in the interest, publicity and sensational journalism [4]. Concern associated with herbal supplements use is the potential exposure to toxic substances, whether as an expected component of the formulation or as an unintended contaminant $[5,6]$.

Natural products extensive use as a source of primary health care should require routine quality control scientific testing methodologies to verify the safety, quality and efficacy of commercially available plant products [7]. This approach will enhance public confidence in the use of such products, which is predominantly in an unregulated environment. Adverse side-effects often associated with the use of traditional/herbal products, are generally due to misidentification of plants, lack of standardization and good manufacturing practices, botanical substitution, adulteration, and contamination. The therapeutic effect of plant medicine is alleged to be enhanced by essential trace elements [8]. Some products may however also contain excessive amounts of trace elements and heavy metals [9]. Trace element and heavy metals could therefore be implicit in causing, contributing or precipitating adverse reaction events [10]. Both trace elements and heavy metals would not necessarily be declared on the product label and consequently becomes an important consideration for this study. The importance of measuring heavy metals and trace metals in particular, is presented in a Herbal Supplement book [5], which points to the contamination of herbal supplements from metals, pharmaceuticals and plant poisoning. Further FDA analyses showed that the greatest contamination associated with metals has been observed in the course of inspection of herbal products imported from Asia [11].

The presence of heavy metals is an example of this concern as case reports have described adverse effects or death, secondary to metal toxicity from supposedly safe 'all natural' products $[5,6]$. The detrimental health outcomes in the longer-term might arise as is illustrated by the following examples; Cadmium (Cd) has a long biological half-life and ingestion over a lifetime results in substantial body burden due to storage in the liver and kidneys, Lead $(\mathrm{Pb}$ ) replaces Calcium ( $\mathrm{Ca}$ ) leading to osteoporosis and may potentiate other genotoxins to induce cancer., while Mercury $(\mathrm{Hg})$ crosses the blood brain barrier and the placenta, inducing neurological damage, and Nickel (Ni) is a known carcinogen and shows wide variability to induce tumors [5].

There is no reason to suspect an offending herbal supplement to be of risk of over exposure to heavy metals until the consumer shows signs of toxicity. Therefore, measuring the presence of these metals in herbal (traditional) supplement products may verify their quality and consistency [5] and reduce the risk associated with unintentional or intentional metal exposure. In this context the revival of interest in the development and discovery of new plant-based medicines [12] is essential. Commercial Ginseng and Hypoxis supplement products are regarded as herbal or plantderived medicines used in primary healthcare, self-medication. These were selected due to their popularity in complementary and alternative medicine practices [13]. Ginseng is a popular traditional Chinese medicine, used for its adaptogenic and restorative properties, and African Potato products is an immune booster for patients infected with HIV/AIDS [14]. The aim of the study was to determine, whether the applicability in use of trace elements and heavy metals in assessing inter-and-intra product batch consistency, and if the fingerprint profiles could be used as an operational quality control approach for reference standard batch-to-batch consistency for specific brand types.

\section{Materials and Methods}

Ginseng and Hypoxis (African potato) commercial product brands were purchased from various pharmacies and health stores in Cape Town, South Africa, with the strategy where possible, of having different batch numbers of the same product. This amounted to 11 products, (Ginseng $n=6$ and Hypoxis $\mathrm{n}=5$ ). There was no prior knowledge of the concentrations for the respective trace elements and heavy metals. The selection of these products allowed for inter-and-intra batch analysis of the trace elements and heavy metal composition. The products were evaluated for content validity and contamination for the following trace element and heavy metals, magnesium (Mg), potassium $(\mathrm{K})$, calcium $(\mathrm{Ca})$, iron $(\mathrm{Fe})$, manganese $(\mathrm{Mn})$, lithium (Li), sodium (Na), chromium (Cr), cobalt (Co), nickel (Ni), copper $(\mathrm{Cu})$, zinc $(\mathrm{Zn})$, strontium $(\mathrm{Sr})$, cadmium $(\mathrm{Cd})$, mercury $(\mathrm{Hg})$ and lead $(\mathrm{Pb})$. The sample digestion procedure prior to analysis followed the accurate weighing of the sample material. The acid digestion was adapted from the Karbochem Research and Development Laboratory. This followed combination of HCL/HF (1:4), Nitric acid and Perchloric acid as part of the procedure.

\section{Inductively Coupled Plasma Mass Spectrometry Methodology}

The trace element and heavy metal content in the products were determined, using the analytical combination tandem system technique of ICP-MS Inductively Coupled Plasma - Mass 
Spectrometry (ICP-MS). ICP-MS is a powerful, accurate, fast and sensitive analytical technique. The Perkin-Elmer 6000 ICPMS instrument and analytical sample preparation procedures were used for the above analysis (Courtesy: Department of Geochemistry, University of Cape Town) $[15,16]$.

\section{Statistical Analysis}

Upon completion of data capturing and analysis of the respective investigations, the following computer-based programmes were used for statistical analysis and graphic representation: Windows-based Microsoft $\AA$ Office Excel 2003 SP1 (Excel@) 1985-2003 Microsoft Corporation), Win Nonlin
Standard Edition Version 1.5 (Win Nonlin@) 1984-1997, Scientific Consulting, Inc.), and Graph Pad Prism $®$ Version 2.01 (Graph Pad Software (C) 1994, 1995, 1996 Graph Pad Software, Inc.). Descriptive data were calculated as means and standard deviations and the coefficient of variation (CV) was computed. Statistical significance was determined where the $\mathrm{p}$ value was $\leq 0.05$. Consistency was accepted where both duplicate sample determination were $\leq 20 \% \mathrm{CV}$ for each trace and heavy metal investigated. The percentage $\mathrm{CV}$ criteria were based on the upper limit of acceptable analytical precision, and within the permissible statistical window for bioequivalence assessment [17-19].

\section{Results}

\section{Products investigated}

Table 1: Ginseng and Hypoxis products investigated.

\begin{tabular}{|c|c|c|c|c|c|c|c|}
\hline \multicolumn{9}{|c|}{ Ginseng } & \multicolumn{3}{c|}{ Hypoxis } \\
\hline Code & Product & Batch & Comparison & Code & Product & Batch & Comparison \\
\hline G1 & AFNG & B/N 403966 & Inter & H1 & IH & 5092 & Inter \\
\hline G2 & AFNG & B/N 403746 & Inter & H2 & IH & Inter/intra \\
\hline G3 & NFNG & $\begin{array}{c}\text { MNF 20 Dec04 } \\
\text { E1 }\end{array}$ & Intra & H3 & IH & 5478 & Inter/intra \\
\hline G4 & NFNG & $\begin{array}{c}\text { MNF 20 Dec04 } \\
\text { E1 }\end{array}$ & Intra & H4 & TAPH & B/N 303 Intra & B/N 303 \\
\hline G5 & BG & 534521 & Inter & H5 & TAPH & Intra \\
\hline G6 & BG & 539702 & Inter & & & & \\
\hline
\end{tabular}

AFNG-Aspen Formule Naturelle Ginseng, NFNG-Natrodale Formule Naturelle Ginseng, BG- Bettaway Ginseng. IH- Inkomfe Hypoxis, TAPHTrazure African Potato Hypoxis.

Table 1 reflects the Ginseng and Hypoxis (African potato) products investigated (Table 1). The products were evaluated for content validity and contamination for the following trace elements and heavy metals; $\mathrm{Mg}, \mathrm{K}, \mathrm{Ca}, \mathrm{Fe}, \mathrm{Mn}, \mathrm{Li}, \mathrm{Na}, \mathrm{Cr}, \mathrm{Co}, \mathrm{Ni}$, $\mathrm{Cu}, \mathrm{Zn}, \mathrm{Sr}, \mathrm{Cd}, \mathrm{Hg}$ and $\mathrm{Pb}$

\section{Statistical evaluation of ginseng and hypoxis formulas}

Samples of Ginseng and Hypoxis formulas (10 tablets or capsules) were randomly selected and evaluated for their mass (in $\mathrm{mg}$ ) consistency statistically, using the unpaired-t-test
(Table 2). The coefficient of variation ranged from 1.3 to $7.2 \%$ for the respective samples. There was a significant difference between the average mass of G5 and G6 (BG different batches) ( $p=0.042)$, and H1 and H2 (IH different batches) ( $p=0.017)$. The samples from the same batches (Ginseng and Hypoxis) were not statistically significantly different. Table 3 summarises the trace element and heavy metals that show intra-sample batch consistency, intra-batch variability, and inter-batch consistency (Table 3). These trace elements and heavy metals may be used as markers, as part of specific product assessment and quality.

Table 2: Comparison of mass for the Ginseng and Hypoxis samples ( $n=10$ in each).

\begin{tabular}{|c|c|c|c|c|c|}
\hline Code & Mass \pm SD (Mg) & Min (Mg) & Max (Mg) & CV (\%) & (P) Value) \\
\hline G1 & $619.2 \pm 14.6$ & 587.6 & 630.3 & 2.4 & 0.903 \\
\hline G2 & $620.0 \pm 15.8$ & 586.5 & 631.5 & 3.6 & 0.394 \\
\hline G3 & $650.6 \pm 21.2$ & 608.2 & 612.8 & 3 & $0.042^{*}$ \\
\hline G4 & $642.7 \pm 19.3$ & 612.8 & 663.9 & 1.3 & \\
\hline G5 & $438.3 \pm 5.8$ & 429.4 & 446.6 & 443.7 & 2.5 \\
\hline G6 & $432.6 \pm 6.4$ & 423.8 & 598.2 & 6.4 & $0.017^{*}$ \\
\hline H1 & $578.0 \pm 13.7$ & 547.6 & 594.1 & & \\
\hline
\end{tabular}




\begin{tabular}{|l|c|c|c|c|c|}
\hline H4 & $513.8 \pm 33.8$ & 479.8 & 580.2 & 6.6 & 0.894 \\
\hline H5 & $516.0 \pm 37.3$ & 476 & 592.1 & 7.2 & \\
\hline
\end{tabular}

The coding and details of each sample are shown in Table 1.

Table 3: Trace element and Heavy metal Inter-and-Intra batch consistency.

\begin{tabular}{|c|c|c|c|c|}
\hline Code & Product & $\begin{array}{l}\text { Intra-sample batch } \\
\text { consistency }\end{array}$ & Intra-batch variability & $\begin{array}{l}\text { Inter-batch sample } \\
\text { consistency }\end{array}$ \\
\hline Ginseng, (G1,G2) & AFNG & $\mathrm{Mg}, \mathrm{K}, \mathrm{Ca}$ & $\begin{array}{c}\mathrm{Fe}, \mathrm{Mn}, \mathrm{Li}, \mathrm{Na}, \mathrm{Cr}, \mathrm{Co}, \mathrm{Ni}, \mathrm{Cu}, \mathrm{Zn} \text {, } \\
\mathrm{Sr}, \mathrm{Cd}, \mathrm{Hg} \text { and } \mathrm{Pb}\end{array}$ & Only for $\mathrm{Ca}$ \\
\hline Ginseng, (G3,G4) & NFNG & $\mathrm{K}, \mathrm{Fe}, \mathrm{Mn}$ & $\begin{array}{c}\mathrm{Mg}, \mathrm{Ca}, \mathrm{Li}, \mathrm{Na}, \mathrm{Cr}, \mathrm{Co}, \mathrm{Ni}, \mathrm{Cu}, \mathrm{Zn} \text {, } \\
\mathrm{Sr}, \mathrm{Cd}, \mathrm{Hg} \text { and } \mathrm{Pb}\end{array}$ & Only for $\mathrm{K}, \mathrm{Fe}, \mathrm{Mn}$ \\
\hline Ginseng, (G5,G6) & BG & $\mathrm{Pb}$ & $\begin{array}{c}\mathrm{Mg}, \mathrm{K}, \mathrm{Ca}, \mathrm{Fe}, \mathrm{Mn}, \mathrm{Li}, \mathrm{Na}, \mathrm{Cr}, \mathrm{Co} \\
\mathrm{Ni}, \mathrm{Cu}, \mathrm{Zn}, \mathrm{Sr}, \mathrm{Cd} \text {, and } \mathrm{Hg}\end{array}$ & No \\
\hline Hypoxis, $(\mathrm{H} 1, \mathrm{H} 2, \mathrm{H} 3)$ & $\mathrm{IH}$ & $\mathrm{Mg}, \mathrm{K}, \mathrm{Mn}, \mathrm{Zn}$ & $\begin{array}{c}\mathrm{Ca}, \mathrm{Fe}, \mathrm{Li}, \mathrm{Na}, \mathrm{Cr}, \mathrm{Co}, \mathrm{Ni}, \mathrm{Cu}, \mathrm{Sr}, \\
\mathrm{Cd}, \mathrm{Hg} \text { and } \mathrm{Pb}\end{array}$ & Only for $\mathrm{Mg}, \mathrm{Mn}$ \\
\hline Hypoxis, $(\mathrm{H} 4, \mathrm{H} 5)$ & TAPH & $\mathrm{Mg}, \mathrm{K}, \mathrm{Ca}, \mathrm{Mn}, \mathrm{Sr}$ & $\begin{array}{c}\mathrm{Fe}, \mathrm{Li}, \mathrm{Na}, \mathrm{Cr}, \mathrm{Co}, \mathrm{Ni}, \mathrm{Cu}, \mathrm{Zn}, \mathrm{Cd}, \\
\mathrm{Hg} \text { and } \mathrm{Pb}\end{array}$ & Only for $\mathrm{Mg}, \mathrm{K}, \mathrm{Ca}, \mathrm{Mn}, \mathrm{Sr}$ \\
\hline
\end{tabular}

Assessment for consistency based on $\leq 20 \%$ CV values. AFNG-Aspen Formule Naturelle Ginseng;

NFNG-Natrodale Formule Naturelle Ginseng; BG-Bettaway Ginseng; IH- Inkomfe Hypoxis;

TAPH- Trazure African Potato Hypoxis

Trace elements and heavy metals in ginseng and hypoxis

Ginseng commercial products assessed showed Table 4 the highest concentrations measured for, $\mathrm{Mg}(7.20 \mathrm{mg} / \mathrm{g}), \mathrm{K}$

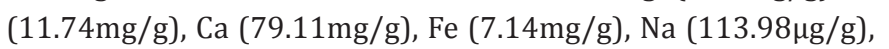
Ni $(4.47 \mu \mathrm{g} / \mathrm{g}), \mathrm{Zn}(59.14 \mu \mathrm{g} / \mathrm{g}), \mathrm{Sr}(99.29 \mu \mathrm{g} / \mathrm{g})$ in $\mathrm{AFNG}$, and
$\mathrm{Hg}(4.14 \mu \mathrm{g} / \mathrm{g})$ in BG. Hypoxis commercial products assessed showed Table 4 the highest concentrations measured for $\mathrm{Li}$ $(48.87 \mu \mathrm{g} / \mathrm{g})$, Co $(3.79 \mu \mathrm{g} / \mathrm{g}), \mathrm{Cu}(17.44 \mu \mathrm{g} / \mathrm{g}), \mathrm{Cd}(0.72 \mu \mathrm{g} / \mathrm{g})$ and $\mathrm{Pb}(49.82 \mu \mathrm{g} / \mathrm{g})$ in IH, and Mn $466(\mu \mathrm{g} / \mathrm{g})$ in TAPH. Chromium was not detected in either of the Ginseng and Hypoxis commercial products analysed (Table 4).

Table 4: Highest element concentrations in Ginseng and Hypoxis Products

\begin{tabular}{|c|c|c|c|c|c|}
\hline \multicolumn{3}{|c|}{ Ginseng } & \multicolumn{3}{|c|}{ Hypoxis } \\
\hline $\mathrm{Mg}$ & AFNG & 7.2 & $\mathrm{Mn}$ & TAPH & 466.1 \\
\hline $\mathrm{K}$ & AFNG & 11.74 & $\mathrm{Li}$ & $\mathrm{IH}$ & 48.87 \\
\hline $\mathrm{Ca}$ & AFNG & 79.11 & Co & $\mathrm{IH}$ & 3.79 \\
\hline $\mathrm{Fe}$ & AFNG & 7.14 & $\mathrm{Cu}$ & $\mathrm{IH}$ & 17.44 \\
\hline $\mathrm{Na}$ & AFNG & 113.98 & $\mathrm{Cd}$ & $\mathrm{IH}$ & 0.72 \\
\hline $\mathrm{Ni}$ & AFNG & 4.47 & $\mathrm{~Pb}$ & $\mathrm{IH}$ & 49.82 \\
\hline $\mathrm{Zn}$ & AFNG & 59.14 & & & \\
\hline $\mathrm{Sr}$ & AFNG & 99.29 & & & \\
\hline $\mathrm{Hg}$ & $\mathrm{BG}$ & 4.14 & & & \\
\hline
\end{tabular}

AFNG- Aspen Formule Naturelle Ginseng; BG- Bettaway Ginseng; TAPH- Trazure African Potato Hypoxis; IH-Inkomfe Hypoxis. Cmax are the highest concentrations in mg/g for $\mathrm{Mg}, \mathrm{K}, \mathrm{Ca}$ and $\mathrm{Fe}$ and in $\mu \mathrm{g} / \mathrm{g}$ for $\mathrm{Mn}, \mathrm{Li}, \mathrm{Na}, \mathrm{Cr}, \mathrm{Co}, \mathrm{Ni}, \mathrm{Cu}, \mathrm{Zn}, \mathrm{Sr}, \mathrm{Cd}, \mathrm{Hg}, \mathrm{Pb}$ measured for commercial Ginseng and Hypoxis products. Cr was not detected in both the Ginseng and Hypoxis products.

\section{Phyto-pharmaceutical enhancing indications and toxicity}

Table 5 summarizes selected trace elements and heavy metals measured in Ginseng and Hypoxis commercial products, their phyto-pharmaceutical enhancing indications, recommended daily upper limits and potential toxic effects in humans due to elevated levels [20,21].

\section{Comparative highest concentration assessment}

In the context of the recommended upper levels for selected trace elements and heavy metals as presented in Table 5, the highest concentration in each product type were determined as presented in Table 6 as an illustration using results obtained in Table 4. This illustration points to the equivalent number of commercial Ginseng and Hypoxis product tablets or capsules 
that have to be consumed to achieve concentrations of $\mathrm{Mg}, \mathrm{K}$, $\mathrm{Ca}, \mathrm{Fe}, \mathrm{Mn}, \mathrm{Na}, \mathrm{Cu}$ and $\mathrm{Zn}$ that may potentially cause adverse events. It is particularly noteworthy to point out that at least nine Ginseng tablets or capsules are needed to be consumed to achieve the upper limit of $40 \mathrm{mg} /$ day for iron (Fe). This is highly relevant since consumers can take higher dosages of product than recommended or prescribed. However, toxicity and adverse effects must be carefully monitored and evaluated from the perspective of synergy among the product's ingredients, i.e., their individual and combined effect(s).

Table 5: Phyto-pharmaceutical enhancing indications and toxicity.

\begin{tabular}{|c|c|c|c|}
\hline Element & Phytopharmaceutical Enhancing Indication & UL* & Description and Toxicity \\
\hline $\mathrm{Ca}$ & $\begin{array}{l}\text { Relieves cough, chronic bronchitis, asthma, } \\
\text { laxative, diuretic, cathartic, vermifuge. }\end{array}$ & $2.5 \mathrm{~g} /$ day & $\begin{array}{l}\text { These trace metals }(\mathrm{Ca}, \mathrm{Na}, \mathrm{K}, \mathrm{Mg} \text { ) are macronutrients and } \\
\text { are required in relatively large amounts in the human diet. } \\
\text { In high doses they may be toxic to the body or produce } \\
\text { deficiencies in other trace metals. Excessive intake of } \mathrm{Ca} \\
\text { result in deposits in soft tissue e.g., kidneys. }\end{array}$ \\
\hline $\mathrm{Na}$ & $\begin{array}{l}\text { Is involved in extracellular and intracellular } \\
\text { fluid balance, and maintenance of blood } \\
\text { viscosity. Na also relieves urinary diseases. }\end{array}$ & $2.3 \mathrm{~g} /$ day & $\begin{array}{l}\text { Plasma Na levels above } 152 \mathrm{~mm} \text { may contribute to coma, } \\
\text { paralysis of lung muscles and death. }\end{array}$ \\
\hline K & $\begin{array}{l}\text { Maintains homeostasis, influences cardiac } \\
\text { muscle activity, relieves urinary diseases, fever, } \\
\text { diarrhoea, cough, chronic bronchitis. }\end{array}$ & $4 \mathrm{~g} /$ day & $\begin{array}{l}\text { Individuals suffering from kidney diseases may suffer } \\
\text { adverse health effects from consuming large quantities of } \\
\text { dietary potassium }\end{array}$ \\
\hline $\mathrm{Mg}$ & $\begin{array}{l}\text { Is essential for the maintenance of cells, } \\
\text { relieves dropsy, piles and boils. It is a purgative } \\
\text { and diuretic. }\end{array}$ & $0.35 \mathrm{~g} /$ day & Excessive intake of Mg leads to diarrhoea. \\
\hline $\mathrm{Fe}$ & $\begin{array}{l}\text { Immune-booster, diuretic, astringent, } \\
\text { demulcent, antipyretic, relieves fever, chronic } \\
\text { rheumatism and psoriasis. }\end{array}$ & $45 \mathrm{mg} /$ day & $\begin{array}{l}\text { Is an important constituent of many enzymes Has an } \\
\text { important role in regulating immune-competence. Known } \\
\text { symptoms of iron toxicity include fatigue, dizziness, nausea, } \\
\text { shortness of breath, headache, vomiting weight loss, } \\
\text { anorexia, and greyish skin colour. }\end{array}$ \\
\hline $\mathrm{Cu}$ & Expectorant, gastric disorders & $10 \mathrm{mg} /$ day & $\begin{array}{l}\text { Constituent of more than eleven important oxidase enzymes } \\
\text { and facilitates various principle metabolic functions. Cu is a } \\
\text { heavy metal and is toxic in its unbound form. Symptoms of } \\
\text { toxicity include hyperactivity, nausea, vomiting, diarrhoea, } \\
\text { fatigue and apathy. }\end{array}$ \\
\hline $\mathrm{Zn}$ & $\begin{array}{c}\text { Relieves fever, ulcer, cough, chronic bronchitis; } \\
\text { increases bio-potency towards infectious } \\
\text { diseases. }\end{array}$ & $40 \mathrm{mg} /$ day & $\begin{array}{l}\text { Plays an important role as cofactor in several enzymatic } \\
\text { reactions. High concentrations may precipitate stomach } \\
\text { cramps; vomiting, nausea; skin irritations and anaemia may } \\
\text { result. }\end{array}$ \\
\hline Mn & $\begin{array}{l}\text { Used as an astringent and to treat scabies, } \\
\text { pneumonia, bronchitis, asthma, headache and } \\
\text { spertamorrhea. }\end{array}$ & $11 \mathrm{mg} /$ day & $\begin{array}{l}\text { Is an essential metal. Symptoms of poisoning include } \\
\text { forgetfulness and nerve damage. A syndrome due to Mn } \\
\text { toxicity has symptoms similar to Schizophrenia, dullness, } \\
\text { weak muscle, headaches and insomnia. }\end{array}$ \\
\hline
\end{tabular}

*UL, upper limit- Dietary Reference Intake (accessed 2017, November 2017). Available from http://en.wikipedia.org/wiki/Dietary_Reference_ Intake

Table 6: Illustrative equivalent upper limit tablet or capsule determination.

\begin{tabular}{|c|c|c|c|c|c|c|c|c|}
\hline \multicolumn{2}{|c|}{$\begin{array}{l}\text { Highest Concentration } \\
\qquad(\mathrm{G} / \mathrm{G})\end{array}$} & \multirow{2}{*}{$\begin{array}{c}\text { Upper Limit } \\
\text { (G) } \\
0.35 \\
\end{array}$} & \multirow{2}{*}{$\begin{array}{l}\text { Mean Tab- } \\
\text { let/ Capsule } \\
\text { (G) } \\
0.62 \\
\end{array}$} & \multirow{2}{*}{$\begin{array}{l}\text { Type } \\
\text { AFNG } \\
\end{array}$} & \multirow{2}{*}{$\begin{array}{l}\text { Brand } \\
\text { Ginseng } \\
\end{array}$} & \multirow{2}{*}{$\begin{array}{c}\text { Factor } \\
139 \\
\end{array}$} & \multirow{2}{*}{$\begin{array}{c}\begin{array}{c}\text { Quantity to } \\
\text { Consume (G) }\end{array} \\
49 \\
\end{array}$} & \multirow{2}{*}{ 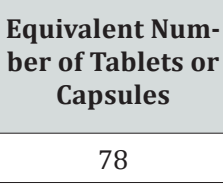 } \\
\hline $\mathrm{Mg}$ & 0.0072 & & & & & & & \\
\hline K & 0.01174 & 4 & 0.62 & AFNG & Ginseng & 85 & 346 & 550 \\
\hline $\mathrm{Ca}$ & 0.07911 & 2.5 & 0.62 & AFNG & Ginseng & 13 & 32 & 51 \\
\hline $\mathrm{Fe}$ & 0.00714 & 0.04 & 0.62 & AFNG & Ginseng & 140 & 6 & 9 \\
\hline $\mathrm{Mn}$ & 0.0004661 & 0.011 & 0.52 & TAPH & Hypoxis & 2145 & 24 & 46 \\
\hline $\mathrm{Na}$ & 0.00011398 & 2.3 & 0.62 & AFNG & Ginseng & 8773 & 20179 & 32547 \\
\hline $\mathrm{Cu}$ & 0.00001744 & 0.01 & 0.58 & $\mathrm{IH}$ & Hypoxis & 57339 & 573 & 992 \\
\hline $\mathrm{Zn}$ & 0.00005914 & 0.04 & 0.62 & AFNG & Ginseng & 16909 & 676 & 1091 \\
\hline
\end{tabular}

AFNG- Aspen Formule Naturelle Ginseng; BG- Bettaway Ginseng; TAPH- Trazure African Potato Hypoxis; IH-Inkomfe Hypoxis 


\section{Fingerprint profiles of Ginseng and Hypoxis products}

Using the trace element and heavy metal analysis data of the commercial Ginseng and Hypoxis products, comparative fingerprint plots were created using logarithmic concentration values. This allowed for comparative profiles of the complete data-set as well as an assessment of product and manufacturing processing consistency. All the trace elements and heavy metals assessed may be classified as contaminants, as they were not described on the label content of the products. Certain trace elements and heavy metals, within given product sample batches showed consistency, in the replicate samples tested. These specific elements could be used as 'markers' for product and batch -to- batch consistency testing.

\section{Ginseng}

Top left (AFNG): The fingerprint profile (Figure 1) was established from quadruplicate samples from two respective batches of AFNG. Based on the criteria of $\leq 20 \% \mathrm{CV}$ and $\mathrm{Mg}, \mathrm{K}$, and Ca showed intra-sample consistency. Calcium was the only trace element with acceptable inter-batch sample consistency. Intra-batch variability were observed for $\mathrm{Fe}, \mathrm{Mn}, \mathrm{Li}, \mathrm{Na}, \mathrm{Co}, \mathrm{Ni}$, $\mathrm{Cu}, \mathrm{Zn}, \mathrm{Sr}, \mathrm{Cd}$, and $\mathrm{Pb}$. $\mathrm{Cr}$ and $\mathrm{Hg}$ was not detected in any of the specific samples.

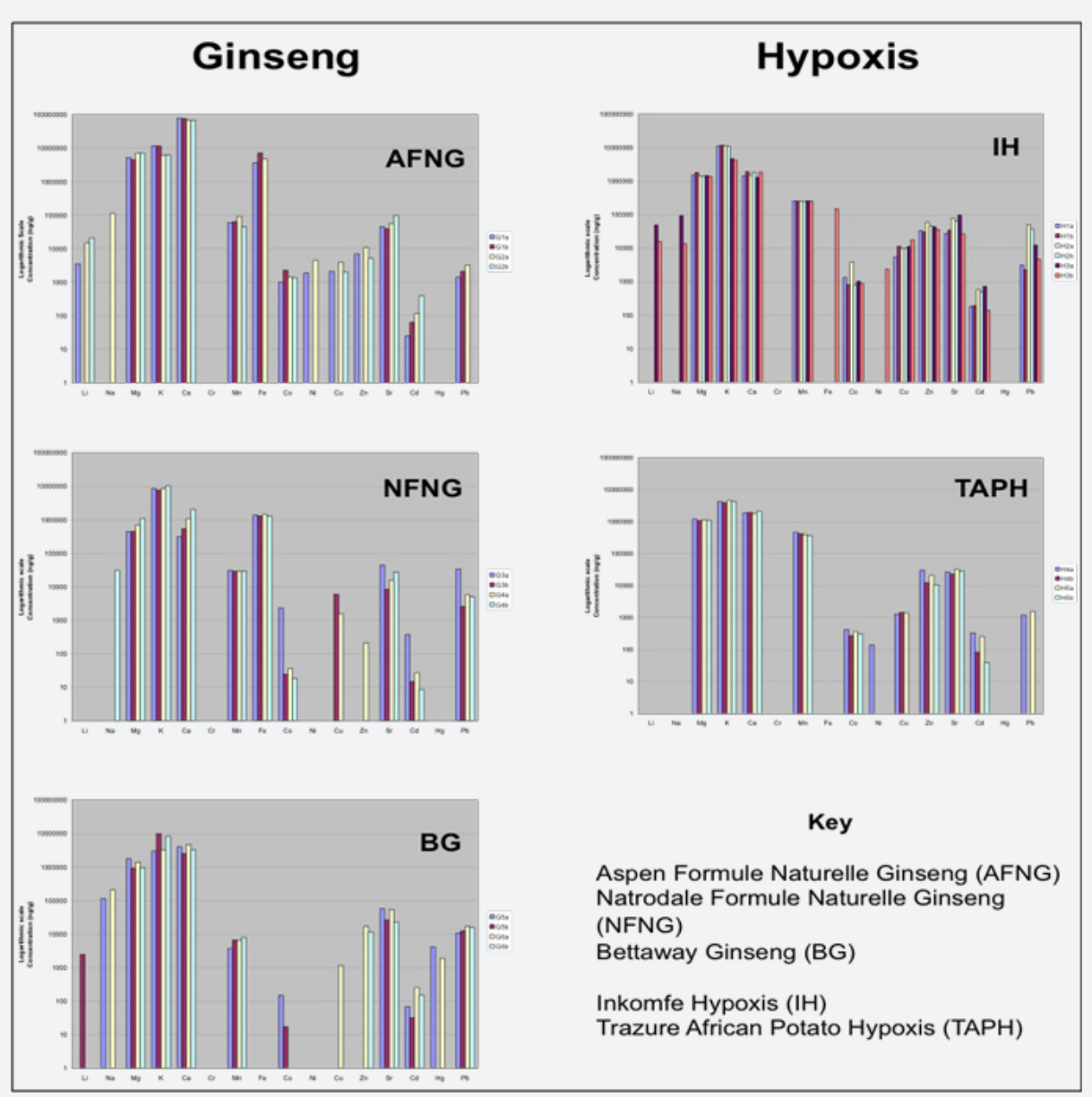

Figure 1: Fingerprint profile of Ginseng and Hypoxis products investigated.

Centre left (NFNG): The fingerprint profile (Figure 1) was established from quadruplicate samples from two respective batches of NFNG. K, Fe and Mn showed intra-sample consistency. $\mathrm{K}, \mathrm{Fe}, \mathrm{Mn}$ also showed inter-batch sample consistency. Intrabatch variability was observed for $\mathrm{Mg}, \mathrm{Ca}, \mathrm{Li}, \mathrm{Na}, \mathrm{Cr}, \mathrm{Co}, \mathrm{Ni}, \mathrm{Cu}$, $\mathrm{Zn}, \mathrm{Sr}, \mathrm{Cd}, \mathrm{Hg}$ and $\mathrm{Pb}$. $\mathrm{Cr}$ and $\mathrm{Hg}$ were not detected in any of the specific samples.

Bottom left (BG): The fingerprint profile (Figure 1) was established from quadruplicate samples from two batches of BG. Pb showed intra-sample batch consistency. Intra-batch variability was observed for $\mathrm{Mg}, \mathrm{K}, \mathrm{Ca}, \mathrm{Mn}, \mathrm{Li}, \mathrm{Na}, \mathrm{Co}, \mathrm{Ni}, \mathrm{Cu}, \mathrm{Zn}$, $\mathrm{Sr}$, and Cd. No Cr, Fe and Ni were detected in the specific samples.

\section{Hypoxis}

Top right (IH): The fingerprint profile (Figure 1) was established from six replicates from three respective batches of IH. Mg, K, Mn, Zn showed intra-sample batch consistency, and inter-batch sample consistency was observed for $\mathrm{Mg}$ and $\mathrm{Mn}$. Intra-batch variability is observed for $\mathrm{Ca}, \mathrm{Fe}, \mathrm{Li}, \mathrm{Na}, \mathrm{Co}, \mathrm{Ni}, \mathrm{Cu}, \mathrm{Sr}$, and $\mathrm{Cd}$. No $\mathrm{Cr}$, Fe and Ni were detected in the specific samples. 
Centre right (TAPH): The fingerprint profile (Figure 1) was established from quadruplicate samples from two respective batches of TAPH. Mg, K, Ca, Mn, Sr had intra-sample batch consistency, and inter-batch sample consistency was observed for $\mathrm{Mg}, \mathrm{K}, \mathrm{Ca}, \mathrm{Mn}$ and $\mathrm{Sr}$. Intra-batch variability was observed for $\mathrm{Co}, \mathrm{Ni}, \mathrm{Cu}, \mathrm{Sr}$, and $\mathrm{Cd}$. $\mathrm{Li}, \mathrm{Na}, \mathrm{Cr}, \mathrm{Fe}$ and $\mathrm{Hg}$ were not detected in the specific samples tested.

\section{Summary of results}

The descriptive data (Table 2) for the Ginseng and Hypoxis tablet or capsule samples generally showed good consistency for mass, as there was no significant difference between samples. However, there were significant differences in mass in the BG product batches G5 and G6 ( $\mathrm{p}=0.042)$, and Inkomfe Hypoxis product batches $\mathrm{H} 1$ and $\mathrm{H} 2(\mathrm{p}=0.017)$ respectively. Table 3 provides a summary of Ginseng and Hypoxis products assessed with respect to the trace element and heavy metals that show intra-sample batch consistency, those that show intra-batch variability, and those that show inter-batch sample consistency. Table 4 provides a comparative assessment of the highest overall element concentrations in the respective Ginseng and Hypoxis products. These findings were used to establish Table 6, which illustrates the upper limit concentration of a given trace element or heavy metal individually, that would be accomplished when consuming a given number of tablets or capsules. The findings suggest the importance of the individual effects of the elements investigated, but also the combined, synergistic effect that may arise. Further, the study shows that; none of the commercial Ginseng and Hypoxis products investigated contained $\mathrm{Cr}$, and the trace elements and heavy metals identified for each specific product, could be used as specific markers for inter and intra batch-to-batch consistency. Further the fingerprint profile(s) can be utilized as important visual tools to assist the process of establishing product quality and consistency on an ongoing basis.

\section{Discussion}

Plant-derived phytochemicals, trace elements and minerals may potentially boost the therapeutic efficacy of complimentary and traditional medicines in foods (CTMF). The large potential of the phyto-pharmaceutical industry in South Africa may be jeopardized by lack of quality control testing procedures and efficient product regulation. It is also important to recognize the individual or collective (combined or synergistic) impact of various trace elements and heavy metals might have on human health and disease, particularly when use in conjunction with conventional drug treatment regimens [14,22,23].

There are many organizations and regulatory bodies that monitor and control the phyto-pharmaceutical industry in South Africa to ensure consumer confidence and satisfaction, including the Direct selling association and Health products association. Validation processes that are key to ensuring the quality, safety and efficacy of natural products include Standard Operating
Procedures (SOPs) for Good Agricultural Practice (GAP), Good Laboratory Practice (GLP), Good Supply Practice (GSP) and Good Manufacturing Practices (GMP). The aforementioned principles and fundamentals need to be established, implemented, regulated and monitored. The findings in this study reveal the need for such measures to be instituted. This study emphasizes that prudent and novel approaches are necessary to ensure that commercially available herbal (traditional) supplement products comply with standard safety and efficacy. It further suggests, that constituents such as trace elements and minerals, along with other constituents in supplement products, should have unique 'fingerprints' to ensure an enabling 'quality control tool for GAP, GMP and GSP, in the interest of consumer safety and satisfaction.

Further, trace element and heavy metal content on Ginseng and Hypoxis supplement labels are not declared. The lack of knowledge of the presence of these elements may have negative consequences as the metals accumulate in the same target organs (e.g. liver and kidney), suggesting that their respective toxicities may be additive. This links to a study by Grippo et al. [10] that shows that the lowest concentration of metal was mostly found in single-ingredient supplements compared to multiple component supplements that generally had higher metal concentrations. According to the studies data, multiple-component supplement products would have a greater probability of contributing to adverse effects [10]. The number of case reports describing toxicity linked to the use of herbal products provides strong evidence that the presence of heavy metals in alternative medicine is a matter of serious concern [5]. The findings also point to the important requirement for qualitative and quantitative assessment of these herbal (traditional) products, to minimize risk to health and wellness, and as suggested by Tovar et al. [2] and Dasgupta et al. [5]. Herbal products are often exported to high-consumption markets, thus spreading the risk of heavy metal toxicity [5]. Whilst findings in this study, based on the Ginseng and Hypoxis products allow for a marker of quality, this does not imply that other similar products may not present higher concentration levels as contaminants, and hence the importance for 'a quality control tool'.

'Finger print' profiling of the trace and heavy metal composition of Ginseng and Hypoxis commercially available products as was used in this study, has the potential to be used as a reference standard against which subsequent manufactured batches can be validated. The proposed (trace elements and heavy metal concentration) approach has the potential to contribute to standardizing consistency the production and quality of traditional herbal medicines brand types. The trace elements and heavy metal respective concentration should be consistent for every brand type. In accordance with this, the two products Ginseng and Hypoxis were systemically analyzed to determine trace element and heavy metal collective profiles that would have practical relevance for herbal product quality assessment. 


\section{Limitation of Study}

The assessment at the time was developed as a proof of concept, using specific the Ginseng and Hypoxis brand of products. This would need to be expanded to other brands in this category that is currently in the market. The period of the study (concluded 2013), and specific products analysed may not represent the current product range. It therefore should not be assumed that that the status quo as presented in this study is the same or similar, as the trace element and heavy metal situation may have 'worsened', as a result of the ongoing changes, and with specific reference to Ginseng and Hypoxis range of products in the South Africa market. Ongoing research, hence needs to be accomplished, that will clarify and provide a possible legislative shift in regulation and policy, in the interest of the health and wellness of the consumer.

\section{Conclusion}

Fingerprint profiles were established for each of the Ginseng and Hypoxis products investigated. Firstly, the fingerprint profiles approach showed reliability as a marker (a quality control tool)to evaluate overall product quality in directly in assessing consistency, and as 'established' for specific brand types. Secondly, to assist more convincingly the potential for metal associated-drug interactions that may previously not have been associated with consumption of the specific products in this study. Further, policy-makers, development agencies and legal frameworks, within and outside the BRICS countries who are responsible for indigenous knowledge systems, would be able to use the trace element and heavy metal 'platform' to share best practice research experiences. This to ensure efficacy and safety of product consumption specifically in the HIV/AIDS setting, but also more generally, the product assessment for a range of herbal (traditional) commercially available products.

\section{Acknowledgement}

The assistance of the South African Medical Research Council, National Research Foundation South Africa, National Institute for the Humanities and Social Sciences (NIHSS)/BRICS Think Tank, the University of Cape Town Research Committee, and the Department of Sport and Movement Studies University of Johannesburg, is hereby acknowledged.

\section{References}

1. Fernanda Leitão, Suzana G Leitão, Mara Zéliade Almeida, Jéssica Cantos, Tatiane Coelho, et al. (2013) Medicinal plants from open-air markets in the State of Rio de Janeiro, Brazil as a potential source of new antimycobacterial agents. J Ethnopharmacol 149(2): 513-521.

2. Tovar RT, Petzel RM (2009) Herbal Toxicity. Dis Mon 55(10): 592-641.

3. Singh YN (2005) Potential for interaction of kava and St. John's wort with drugs. J Ethnopharmacol 100(1-2): 108-113.

4. Sirven JI, Drazkowski JF, Zimmerman RS, Bortz JJ, Shulman DL, et al. (2003) Complementary/alternative medicine for epilepsy in Arizona.
Neurology 61(4): 576-577.

5. Dasgupta A, Hammett-Stabler C (2011) Herbal supplements- efficacy, toxicity, interactions with western drugs, and effects on clinical laboratory tests. Willey

6. Yee SK, Chu SS, Xu YM, Choo PL (2005) Regulatory control of chinese proprietary medicines in singapore. Health Policy 71 (2): 133-149.

7. Ashish K Sharma, Rajesh Kumar, Anurag Mishra, Rajiv Gupta (2010) Problems associated with clinical trials of Ayurvedic medicines. Brazilian Journal of Pharmacognosy 20(2): 276-281.

8. Mulholland DA (2005) The future of ethnophamacology-A Southern African perspective. J Ethnopharmacol 100(1-2): 124-126.

9. Chunhong Zhang, Qianquan Li, Muxin Zhang, Na Zhang, Minhui Li (2013) Effects of rare earth elements on growth and metabolism of medicinal plants. Acta Pharmaceutica Sinica B 3(1): 20-24.

10. Grippo AA, Hamilton B, Hannigan R, Gurley B (2006) Metal content of ephedra-containing dietary supplements and select botanicals. Am J Health Syst Pharm 63(7): 635-644.

11. Smolinske SC (2005) Herbal product contamination and toxicity. Journal of Pharmacy Practice 18(3): 188-208.

12. Calixto J (2005) Twenty-five years of research on medicinal plants in Latin America: a personal view. J Ethnopharmacol 100(1-2): 131-134.

13. Harkey MR, Henderson GL, Gershwin ME, Stern JS, Hackman RM (2001) Variability in commercial ginseng products: an analysis of 25 preparations. Am J Clin Nutr 73(6): 1101-1106.

14. Rudy Onia (2005) Complementary, Alternative and Traditional Medicines and HIV and Aids. CME 23(5): 260.

15. Anton P Roex, Spath A, Robert E Zartman (2001) Lithospheric thickness beneath the southern Kenya Rift: implications from basalt geochemistry. Contribution to Mineralogy and Petrology 142(1): 89106.

16. Avegliano RP, Maihara VA, Fabio Fernando da Silva (2011) A Brazilian total diet study: Evaluation of essential elements Journal of Food Composition and Analysis. 24(2011): 1009-1016.

17. Steinijans V, Hauschke D, Elze M (1995) Metrics to characterize concentration-time profiles in single- and multiple-dose bioequivalence studies. Drug Information Journal 29(3): 981-987.

18. Steinijans V, Hauschke D, Schall R (1995) International harmonization of Regulatory requirements for average bioequivalence and current issues in individual bioequivalence. Drug Information Journal 29(3):1055-1062.

19. Gabriels GA, Mcllleron H, Smith PJ, Folb PI, Fourie PB (2007) Modification to improve efficiency of sampling schedules for BA/ BE testing of FDC anti-tuberculosis drugs. International Journal of Tuberculosis and Lung Disease 11(2): 181-188.

20. Welham J (2005) Complementary and traditional medicines in South Africa. Vital News, Third Quarter 14-17.

21. Udayakumar R, Begun V (2004) Elemental Analysis of Medicinal Plants used in controlling infection diseases. Hamdard Medicus (4): 35-39.

22. Mohamed Ali Hegazi (2014) The trace elements in congenital cyanotic heart disease. The Egyptian Heart Journal 66(1): 1-25.

23. Jay Prakash Rajan, Kshetrimayum Birla Singh, Sanjiv Kumar, Raj Kumar Mishra (2014) Trace elements content in the selected medicinal plants traditionally used for curing skin diseases by the natives of Mizoram, India. Asian Pac J Trop Med 7(S1): S410-414. 
This work is licensed under Creative Commons Attribution 4.0 Licens

DOI: 10.19080/JCMAH.2017.04.5556467
Your next submission with Juniper Publishers will reach you the below assets

- Quality Editorial service

- Swift Peer Review

- Reprints availability

- E-prints Service

- Manuscript Podcast for convenient understanding

- Global attainment for your research

- Manuscript accessibility in different formats

( Pdf, E-pub, Full Text, Audio)

- Unceasing customer service

Track the below URL for one-step submission https://juniperpublishers.com/online-submission.php 